\title{
RESPONS MASYARAKAT TERHADAP PENGENALAN TANAMAN GANDUM DAN PRODUK- PRODUKNYA DI DESA ARJASARI KECAMATAN ARJASARI KABUPATEN BANDUNG
}

\author{
Fiky Yulianto Wicaksono, Yudithia Maxiselly, Tati Nurmala, Putri Utami Suherman, \\ Alfika Fauzan, dan Andala Muhamad Nurdin \\ Program Studi Agroteknologi Fakultas Pertanian Universitas Padjadjaran \\ E-mail: fiky.yulianto@unpad.ac.id
}

\begin{abstract}
ABSTRAK. Desa Arjasari adalah sebuah desa yang berada di pegunungan yang terletak di kaki gunung Malabar, Kabupaten Bandung. Sebagian besar wilayah terdiri dari lahan pertanian. Sebagian besar mata pencaharian warga adalah buruh tani dan petani. Salah satu masalah usaha tani di desa Arjasari adalah diversifikasi tanaman yang diusahakan dan ketidakmampuan petani untuk menanam tanaman selama musim kemarau. Gandum dapat dijadikan salah satu komoditas untuk diversifikasi dan relatif tahan terhadap kekeringan di daerah dengan kelembaban tinggi sehingga dapat ditanam di musim kemarau. Pengenalan tanaman gandum dan produk-produknya di Desa Arjasari memiliki tujuan mensosialisasikan tanaman gandum di masyarakat sehingga masyarakat tertarik mengembangkannya, diantaranya dengan cara meningkatkan pemahaman masyarakat mengenai kegunaan tanaman gandum, teknik budidayanya, serta produk-produknya. Kegiatan ini menggunakan metode penyuluhan tanaman gandum, produk gandum, teknik budidayanya, dan pembuatan demplot partisipatif. Kuesioner dibagikan pada peserta penyuluhan sebelum dan sesudah penyuluhan. Data yang diperoleh dari kuesioner kemudian dianalisis menggunakan uji statistik deskriptif. Waktu pelaksanaan dari bulan Juli hingga November 2017. Sasaran kegiatan ini adalah ibu-ibu PKK dan wanita tani. Respons masyarakat terhadap pengenalan tanaman gandum dan produk-produknya di Desa Arjasari sangat baik. Hal ini terlihat setelah penyuluhan bahwa masyarakat tertarik menanam gandum dan membuat produk-produk dari gandum. Variabel yang berhubungan dengan ketertarikan masyarakat mengembangkan gandum adalah umur, pengenalan produk sebelumnya, pernah tanam sebelumnya, dan minat menambah penghasilan.
\end{abstract}

Kata kunci: gandum, arjasari, lahan kering

\section{COMMUNITY RESPONSE TO RICE PRODUCT INTRODUCTION AND ITS PRODUCTS IN ARJASARI VILLAGE ARJASARI DISTRICT BANDUNG REGENCY}

\begin{abstract}
Arjasari is a village that located at the foot of Malabar mountain, Bandung. Most of the area consists of agricultural land. Most of workers are farm laborers and farmers. The problems of farming in Arjasari is diversification of cultivated species and inability of farmers to grow crops during dry season. Wheat can be one of the commodities to diversify and relatively resistant to drought in high humidity areas so it can be grown in the dry season. Socialization of wheat crop and their products. The socialization of wheat crops and their products in Arjasari Village has the goal, there is informing wheat crops in the society so that people are interested in developing them by improving the community's understanding of the usefulness of wheat crops, cultivation techniques, and their products. This activity used counseling about what is wheat crops, wheat products, cultivation techniques, and making demonstration plots. Questionnaires were distributed to the counseling participants before and after counseling. Data that obtained from the questionnaire were then analyzed using descriptive statistical test. The activity was conducted from July to November 2017. The target of this activity were women activist of family welfare and women farmers. Public response to the introduction of wheat crops and its products in Arjasari Village was very good. It is seen after counseling that people were interested in growing wheat and making products from wheat. Variables that have a correlation with respondent interest in developing wheat were farmer's age, previous information of product, previous cropping, and interest income.
\end{abstract}

Keywords: wheat, arjasari, dry land

\section{PENDAHULUAN}

Desa Arjasari adalah sebuah desa yang berada di pegunungan yang terletak di kaki gunung Malabar, Kabupaten Bandung, merupakan desa pemekaran dari Desa Lebakwangi Kecamatan Pameungpeuk Kabupaten Bandung. Berdasarkan monografi desa, wilayah Desa Arjasari terletak di ketinggian kurang lebih $700-1.000$ $\mathrm{m}$ diatas permukaan laut dengan suhu rata-rata $28 \mathrm{oC}$ dengan curah hujan rata - rata $3.560 \mathrm{~mm} /$ tahun. dengan luas wilayah 768,848 Ha. Sebagian besar wilayah terdiri dari dari lahan pertanian (sawah, lahan kering, hutan, dan perkebunan negara) serta fasilitas umum/ perumahan penduduk.
Jumlah penduduk Desa Arjasari, Kecamatan Arjasari, Kabupaten Bandung, sampai dengan akhir bulan Desember 2013 adalah 10.345 Jiwa yang terdiri dari 5.222 Jiwa penduduk laki-laki dan 5.123 Jiwa penduduk perempuan dengan jumlah Kepala Keluarga (KK) 3.004 Kepala Keluarga. Mata pencaharian warga Desa Arjasari mayoritas adalah sebagai buruh tani. Sebanyak 31\% dari warga yang bekerja adalah buruh tani, dan sisanya adalah petani, pegawai swasta, pedagang dll. Mayoritas penduduk asli Desa Arjasari bermata pencaharian sebagai petani dan buruh tani, hal ini merupakan suatu kegiatan yang telah dilakukan secara turun temurun oleh mayoritas penduduk asli Desa Arjasari. Sementara mayoritas penduduk pendatang Desa Arjasari memiliki mata 
pencaharian yang beragam seperti pedagang, wirausaha.

Ada sekitar 6 kelompok tani di DesaArjasari dengan komoditas utama adalah jagung manis, berdasarkan data diatas dapat disimpulkan bahwa sektor pertanian mempunyai peran yang besar dalam perekonomian keluarga di Arjasari. Kelompok tani di Desa Arjasari belum berfungsi secara maksimal dikarenakan kelompok masih berfungsi sebagai penghimpun bantuan subsidi berupa bantuan pupuk dan benih dari pemerintah, selain itu penyuluhan di Desa Arjasari masih terfokus pada komoditas jagung sehingga potensi tanaman lain masih belum maksimal. Padahal diversifikasi jenis tanaman dapat membuat risiko kerugian usaha tani menjadi lebih rendah. Rendahnya penyuluhan pada sektor tanaman lain membuat tidak optimalnya produksi dari komoditas lain. Selain itu, petani di Desa Arjasari masih bergantung pada tengkulak, sehingga rantai pemasaran produk pertanian cukup panjang dan harga yang diterima pada petani juga terkategori rendah. Masalah lain di bidang pertanian adalah ketidakmampuan petani untuk menanam tanaman di lahan kering selama musim kemarau sehingga lahan menjadi bera (tidak ditanami). Hal ini disebabkan sarana irigasi teknis masih minim.

Untuk memecahkan masalah diversifikasi tanaman dan pemanfaatan lahan bera dapat dilakukan dengan penanaman gandum. Gandum (Triticum aestivum L.) merupakan salah satu tanaman serealia yang dibutuhkan untuk pangan manusia. Gandum juga dapat dimaanfatkan sebagai pakan ternak. Gandum digunakan dalam industri makanan sebagai bahan baku pembuatan tepung terigu. Tepung terigu dapat diproses lebih lanjut menjadi roti, kue, spagheti, macaroni, dan lain-lain (Nurmala, 1998). Produksi gandum merupakan produksi tanaman pangan terbesar kedua di dunia setelah jagung. Produksi gandum dunia tahun 2015 mencapai 735,5 juta ton (World Wheat Production, 2016).

Gandum menjadi bahan makanan pokok kedua setelah beras di Indonesia. Gandum mempunyai kandungan gluten yang tinggi sehingga memberikan daya kembang pada adonan. Hal ini yang membuat gandum tidak tergantikan sebagai bahan baku tepung terigu. Produk olahan dari terigu sangat beragam saat ini sehingga permintaan terigu meningkat. Permintaan gandum yang tinggi tidak diimbangi oleh produksi dalam negeri. Kebutuhan terigu di Indonesia pada tahun 2014 mencapai 5,4 juta metrik ton. Kebutuhan ini dipenuhi dari impor gandum sebesar 7,4 juta metrik ton yang menjadikan Indonesia sebagai importir gandum terbesar ke-4 dunia setelah Mesir, Cina, dan Brazil (Aptindo, 2014).

Penanaman gandum di dataran medium, seperti Arjasari, menjadi penting karena sampai saat ini penanaman gandum di dataran tinggi tidak dapat bersaing dengan komoditas sayuran (Nurmala dkk, 2007). Produksi gandum di lahan kering dataran medium masih rendah akibat suhu yang lebih tinggi dibandingkan dataran tinggi. Hal ini yang menyebabkan tanaman gandum terkena cekaman panas (heat stress).
Beberapa rekayasa, baik ekologi maupun fisiologi, dapat diterapkan untuk mencegah cekaman panas pada tanaman gandum di dataran medium sehingga hasil gandum dapat meningkat di dataran medium (Wicaksono, 2017). Rekayasa-rekayasa tersebut diantaranya adalah pemberian antioksidan, pemberian zat pengatur tumbuh, pengaturan jarak tanam, dan pemberian hara silika. Pemberian antioksidan atau pemberian hara silika dapat mengurangi cekaman panas dan meningkatkan pertumbuhan dan hasil tanaman, sementara pemberian zat pengatur tumbuh dapat mengurangi cekaman panas dan meningkatkan pertumbuhan tanaman.

Gandum relatif tahan terhadap kekeringan di daerah dengan kelembaban tinggi sehingga dapat ditanam pada lahan bera di musim kemarau. Hal ini disebabkan rambut pada malai dapat menyerap uap air sehingga tanaman tidak kekurangan air. Berkembangnya produk-produk gandum, seperti kecambah gandum dan jus rumput gandum, dapat menarik minat masyarakat untuk mengembangkan tanaman gandum.

Pengenalan tanaman gandum dan produkproduknya di Desa Arjasari memiliki tujuan mensosialisasikan tanaman gandum di masyarakat sehingga masyarakat tertarik mengembangkannya, diantaranya dengan cara meningkatkan pemahaman masyarakat mengenai kegunaan tanaman gandum, teknik budi dayanya, serta produk-produknya. Penanaman gandum lokal di masyarakat diharapkan dapat terwujud dan berkelanjutan. Hal ini juga diharapkan pada produksi produk gandum lokal.

\section{METODE}

Pengenalan tanaman gandum dan produk-produknya dilakukan di Desa Arjasari, Kecamatan Arjasari, Kabupaten Bandung, mulai bulan Juli sampai dengan November 2017. Sasaran kegiatan ini adalah ibu-ibu PKK dan wanita tani. Pemilihan sasaran ter-sebut disebabkan para ibu diharapkan nantinya dapat membujuk suaminya untuk mengembangkan tanaman gandum. Kegiatan ini menggunakan metode penyuluhan dan demplot partisipatif. Materi penyuluhan dibuat oleh tim dosen berdasarkan hasil-hasil penelitian. Pembuatan demplot partisipatif dilakukan bersama-sama oleh masyarakat serta dosen yang dibantu oleh para mahasiswa. Materi penyuluhan berisi mengenai:

1. Pengenalan tanaman gandum, baik morfologi, daerah asal, dan syarat tumbuhnya.

Materi morfologi tanaman gandum mengenai penggolongan tanaman gandum berdasarkan klasifikasi botani dan agronomi. Penjelasan daerah asal tanaman gandum berisi tentang daerah asal dan penyebarannya. Syarat tumbuh tanaman gandum berisi tentang kesesuaian tanah dan iklim yang dibutuhkan oleh tanaman gandum untuk tumbuh. 
2. Pengenalan produk tanaman gandum

Materi pengenalan produk tanaman gandum mengenai produk-produk dari tanaman gandum, diantaranya adalah tepung gandum, tepung terigu, jus rumput gandum, dan kecambah gandum. Pemaparan produkproduk ini dilanjutkan dengan pengenalan produk secara fisik.

3. Materi tentang teknologi budidaya gandum di dataran medium

Teknologi budidaya gandum di dataran medium dimulai dari tahapan sebelum tanam sampai panen. Tahapan tersebut diantaranya adalah persiapan benih, pengolahan lahan, persiapan tanam, teknologi penanaman, pemeliharaan tanaman (pemupukan, pengendalian organisme pengganggu tanaman, dan manajemen air), dan teknologi panen. Materi ini juga membahas mengenai rekayasa teknologi budidaya yang dibutuhkan tanaman gandum untuk mengurangi cekaman panas di dataran medium, seperti pemberian antioksidan (kalsium klorida dan asam salisilat), pengaturan jarak tanam, pemberian zat pengatur tumbuh (sitokinin dan giberelin), serta pemberian hara silika (Wicaksono, 2017).

4. Materi tentang teknologi pascapanen gandum

Materi ini berisi teknologi pengemasan dan penyimpanan biji/benih gandum. Materi ini diberikan agar peserta penyuluhan mengetahui cara mengemas dan menyimpan biji/benih gandum agar tahan lama.

Kuesioner dibagikan pada peserta penyuluhan sebelum dan sesudah penyuluhan untuk mengetahui tingkat pengetahuan awal petani mengenai gandum dan budidayanya, mengetahui keberhasilan metode PKM yang dijalankan, dan menampung saran petani mengenai metode PKM yang dijalankan sehingga metode dapat dimutakhirkan untuk PKM selanjutnya. Kuesioner dibagikan dalam bentuk pre-test dan posttest. Kuesioner sebagai alat untuk menampung data sehingga kegiatan ini dapat dicatat dengan data yang sahih. Kuesioner berisi pertanyaan mengenai:

1. Peserta penyuluhan apakah sebelumnya telah mengenal gandum dan produk turunannya. Hal ini untuk melihat kesiapan dari peserta sebelum penyuluhan.

5. Peserta penyuluhan apakah sebelumnya dapat membedakan tepung gandum dan tepung terigu. Hal ini agar peserta tahu bahwa sebenarnya tepung gandum dan tepung terigu sama-sama produk dari gandum.

6. Apakah sebelumnya peserta penyuluhan mengenal produk-produk gandum yang lain, seperti jus rumput gandum atau kecambah gandum. Hal ini untuk mengetahui pengetahuan peserta penyuluhan tentang produk gandum.

7. Apakah sebelumnya peserta penyuluhan pernah menanam gandum. Hal ini untuk mengetahui kesiapan peserta dalam membudidayakan gandum.

8. Seberapa besar penghasilan yang ingin diperoleh oleh peserta penyuluhan dalam mengembangkan tanaman gandum. Hal ini untuk mengukur seberapa besar pengembangan gandum di desa Arjasari.

9. Peserta penyuluhan apakah ingin memasarkan produk gandum secara mandiri. Hal ini untuk mengukur tingkat kemandirian peserta penyuluhan dalam memasarkan produk gandum. Hal ini juga dijadikan acuan bagi fasilitator sebagai bahan pendampingan dalam pemasaran produk gandum.

10. Peserta penyuluhan apakah tertarik untuk menanam gandum, terutama di masa bera. Hal ini untuk mengukur keberhasilan program pada tahap awal dan menentukan strategi program berikutnya.

11. Peserta penyuluhan apakah menganggap ada kesulitan untuk menanam gandum. Hal ini untuk menentukan strategi pendampingan dalam budidaya gandum

12. Peserta penyuluhan apakah akan memelihara demplot pertanaman gandum. Hal ini untuk melihat partisipasi dan kerjasama peserta dalam memelihara demplot pertanaman gandum.

Data yang diperoleh dari kuesioner kemudian dianalisis menggunakan uji statistik deskriptif yaitu dengan menggunakan ukuran pemusatan, ukuran penyebaran, dan uji korelasi rank Spearman dalam taraf nyata 5\% (Budiarto, 2001).

\section{HASIL DAN PEMBAHASAN}

Kegiatan penyuluhan utamanya mengenalkan tanaman gandum beserta produknya pada ibu-ibu PKK dan ibu wanita tani, yang dilanjutkan dengan pengenalan teknologi budidaya dan pasca panen tanaman gandum di lahan kering. Penyuluhan dilakukan di gedung serbaguna Desa Arjasari, Kecamatan Arjasari, Kabupaten Bandung. Diskusi dalam penyuluhan ini lebih diarahkan pada pembuatan produk gandum dan pembahasan mengenai teknologi budidaya gandum. Hal ini dimaksudkan agar para peserta penyuluhan lebih tertarik pada budidaya gandum dan pembuatan produkproduknya. Selain itu, pada diskusi ini juga disisipi uji rasa (uji organoleptik) produk gandum yang dibuat oleh mahasiswa yang sedang penelitian budidaya tanaman gandum.

Penyebaran kuesioner juga dilakukan untuk mengetahui serapan pengetahuan oleh peserta penyuluhan. Sebanyak 20 responden dipilih dengan rata-rata umur responden adalah 43,7 tahun (Gambar 1).

Berdasarkan status kepemilikan lahan, sebagian besar responden tidak mempunyai lahan (berprofesi sebagai pengolah hasil pertanian), sisanya mempunyai lahan sendiri dan menyewa lahan ke orang lain (Gambar 


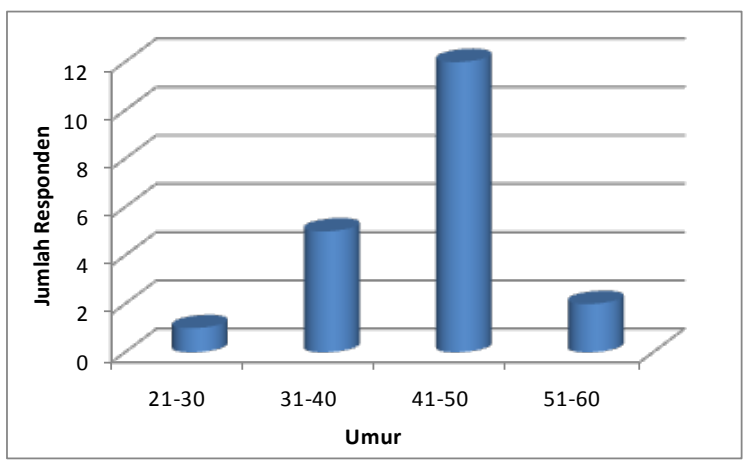

Gambar 1. Grafik Umur Responden

Keterangan: rata-rata umur responden 43,7 tahun (standar deviasi 7,4 tahun)

2). Rata-rata luas lahan kering yang diusahakan adalah $1657,6 \mathrm{~m} 2$. Komoditas yang diusahakannya adalah tanaman semusim dan tanaman tahunan. Tanaman semusim diantaranya adalah jagung dan singkong, sementara tanaman tahunan yang diusahakan adalah kopi dan tanaman penghasil kayu.

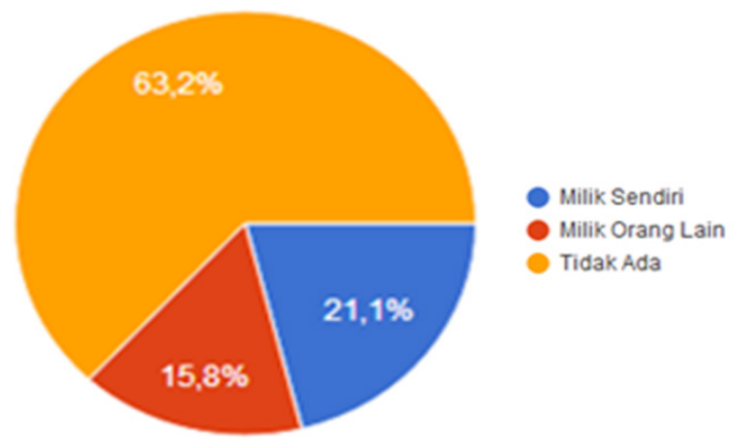

Gambar 2. Grafik Status Kepemilikan Lahan

Hasil kuesioner pre-test menunjukkan bahwa sebelum ada penyuluhan, sebanyak 78,9\% responden sudah mengenal tanaman gandum, namun sebanyak $21,1 \%$ belum mengenal tanaman gandum. Beberapa peserta penyuluhan belum mengetahui semua produk gandum, meskipun $100 \%$ sudah mengetahui bahwa terigu merupakan produk dari tanaman gandum. Sebanyak $42,1 \%$ responden telah mengenal tepung gandum, namun $57,9 \%$ belum mengenal tepung gandum. Responden yang dapat membedakan tepung gandum dan tepung terigu, baik dari bentuknya maupun dari proses pengolahannya adalah sebanyak $31,6 \%$, sementara responden yang belum dapat membedakan tepung gandum dan tepung terigu adalah $68,4 \%$. Sebanyak $78,9 \%$ responden belum mengenal kegunaan yang lain dari tanaman gandum sementara baru $21,1 \%$ responden yang sudah mengenal kegunaan yang lain dari tanaman gandum.

Data tersebut menunjukkan bahwa meskipun sebagian besar dari responden telah mengenal tanaman gandum, namun produk yang diketahuinya baru sebatas tepung terigu. Sebagian kecil responden saja yang mengenal kegunaan gandum yang lain selain tepung terigu, beberapa responden belum tahu bentuk tepung gandum bahkan belum bisa membedakan tepung gandum dan tepung terigu.

Peserta penyuluhan sudah ada yang telah menanam gandum. Sebanyak 31,6\% responden mengaku pernah menanam gandum, sedangkan sisanya belum pernah menanam gandum. Semua (100\%) responden berminat menanam gandum secara berkelanjutan bila dapat menambah penghasilan, meskipun terdapat kesulitankesulitan dalam teknik budidayanya. Faktor tunggal yang paling menentukan semangat masyarakat terhadap program yang kita tawarkan adalah peningkatan pendapatan perorangan yang dapat dicapai dengan ide program yang kita tawarkan (Bunch, 2001).

Masyarakat sebenarnya sudah pernah ada yang menanam gandum. Kelompok ini dapat menjadi agent of change dan dapat membujuk masyarakat yang lain untuk menanam tanaman gandum. Masyarakat sebenarnya berminat untuk menanam gandum meskipun sulit dilakukan karena memerlukan rekayasa budidaya supaya dapat tumbuh optimal di dataran medium. Minat menanam gandum dengan syarat kegiatan tersebut dapat menambah penghasilan. Namun, masyarakat masih banyak yang belum berminat untuk memasarkan produknya sendiri karena belum mengetahui potensi/ kelebihan dari produk gandum. Sebanyak 42,1\% responden belum mau memasarkan produknya sendiri, sementara 57,9\% responden berminat memasarkan produknya sendiri.

Setelah penyuluhan, semua responden (100\%) telah mengenal tanaman gandum, mengenal tepung gandum, dapat membedakan tepung gandum dengan tepung terigu, dan mengenal berbagai produk gandum lainnya, seperti kecambah gandum dan jus rumput gandum. Tujuan lain dari penyuluhan ini untuk mengajak peserta penyuluhan untuk mengembangkan budidaya gandum dan produknya dapat tercapai. Semua responden berminat untuk memproduksi produk-produk gandum. Hal ini menandakan tujuan penyuluhan untuk mengenalkan tanaman gandum dan produk-produknya telah tercapai. Salah satu faktor yang mempengaruhi percepatan adopsi dan difusi inovasi adalah tepat tidaknya dalam menggunakan metode penyuluhan. Penggunaan metode yang efektif akan mempermudah untuk dipahami oleh petani (Musyafak dan Ibrahim, 2005).

Ketertarikan terhadap tanaman gandum dilihat dari keinginan untuk menanam di saat musim kemarau atau di saat lahan bera. Sebanyak 89,5\% responden tertarik untuk menanam gandum, sisanya $10,5 \%$ tidak tertarik menanam gandum. Responden yang tertarik menanam gandum ingin budidaya gandum dilakukan di halaman rumah, kebun, ladang, dan polybag (Gambar 3). Sebanyak $73,7 \%$ responden ingin menanam gandum di masa bera, sedangkan sebanyak 26,3\% responden tidak tertarik menanam gandum di masa bera. Hal ini disebabkan kondisi lahan mereka yang betul-betul mengandalkan air hujan untuk penyiraman pada awal tanam. 
Alfika Fauzan dan Andala Muhamad Nurdin

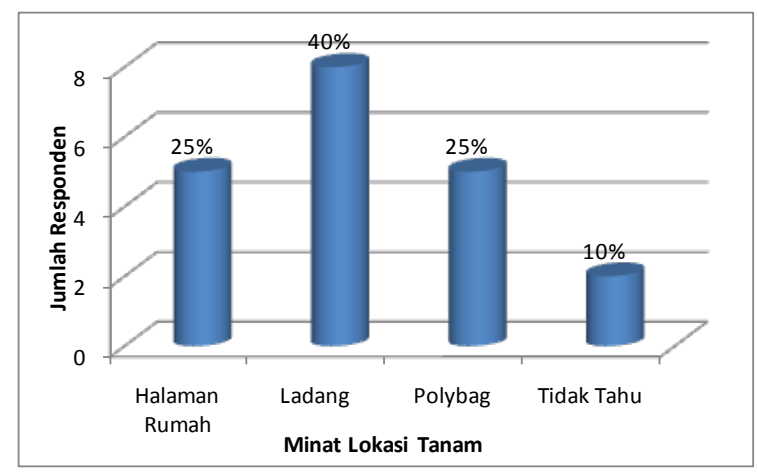

Gambar 3. Grafik minat lokasi penanaman gandum

Peserta penyuluhan telah meramalkan kesulitankesulitan yang akan dihadapi dalam membudidayakan tanaman gandum (Gambar 4). Beberapa kesulitan tersebut diantaranya adalah media tanam, modal, pemeliharaan, tempat, dan pemasaran. Peserta penyuluhan menganggap sulit menyediakan campuran pupuk organik silika dan kompos yang akan dicampurkan dengan tanah. Hal ini menjadi keharusan untuk menyediakan media tanam alternatif lokal yang tersedia di sana. Saat ini yang tersedia adalah arang sekam sehingga arang sekam menjadi media tanam alternatif. Modal dianggap sulit karena modal diambil dari modal usaha tani yang lain. Pemeliharaan dianggap sulit karena beberapa lokasi betul-betul tidak mempunyai sumber air (juga berhubungan dengan tempat). Hal ini dapat disiasati dengan pembuatan pola tanam (Nurmala, et.al., 2015).

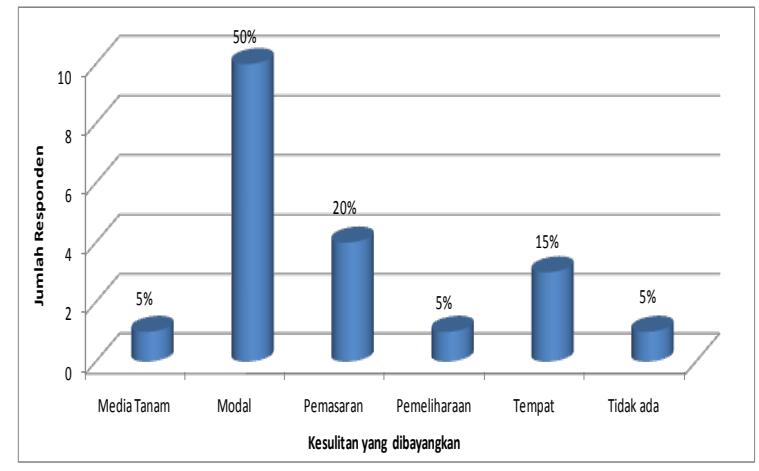

Gambar 4. Grafik opini kesulitan yang dibayangkan dalam penanaman gandum

Pemasaran dianggap menjadi kesulitan oleh peserta penyuluhan karena mereka menganggap harus membuat pasar produk gandum sendiri. Hal ini yang nantinya akan difasilitasi oleh tim PKM untuk membuat pemasaran yang berkelanjutan. Sebanyak $73,7 \%$ responden memandang pemasaran gandum sebagai kesulitan, sementara 26,3\% menganggap pemasaran gandum dapat berjalan berkelanjutan bila kualitas produknya sudah baik. Bila kita menginginkan masyarakat menerima suatu ide yang kita tawarkan, masyarakat harus diyakinkan dulu bahwa ide tersebut akan memenuhi suatu kebutuhan yang benar-benar dirasakan (Bunch, 2001).

Ketertarikan masyarakat mengembangkan gandum (menanam gandum dan membuat produknya) dipeng- aruhi oleh beberapa hal. Berdasarkan uji korelasi rank Spearman, terdapat beberapa variabel yang signifikan berhubungan dengan ketertarikan masyarakat menanam gandum dan membuat produknya (Tabel 1).

Tabel 1. Nilai korelasi antara ketertarikan masyarakat mengembangkan gandum dengan beberapa variabelnya

\begin{tabular}{lc}
\hline \multicolumn{1}{c}{ Variabel } & Koefisien korelasi \\
\hline umur & $0.0107 *$ \\
luas lahan & -0.1484 \\
pengenalan tanaman sebelumnya & 0.1400 \\
pengenalan produk sebelumnya & $0.2100 *$ \\
pernah tanam sebelumnya & $0.2750 *$ \\
minat menambah penghasilan & $0.2157 *$ \\
\hline
\end{tabular}

Keterangan: * korelasi signifikan pada taraf uji 5\%

Variabel yang berhubungan dengan ketertarikan masyarakat mengembangkan gandum adalah umur, pengenalan produk sebelumnya, pernah tanamn sebelumnya, dan minat menambah penghasilan. Budidaya gandum sebenarnya relatif mudah, sehingga petani yang sudah semakin tua pun masih tertarik untuk menanamnya. Teknologi untuk para petani harus menggunakan sumberdaya yang sudah mereka miliki (Bunch, 2001), dalam hal ini tentu saja petani itu sendiri yang nantinya akan mengembangkannya. Pengenalan produk sebelum penyuluhan dan pernah tanam gandum sebelumnya menjadi informasi tambahan bagi responden sebelum penyuluhan. Faktor ketersediaan informasi menentukan tingkat adopsi inovasi oleh petani/ masyarakat (Hasanuddin, 2005). Minat menambah penghasilan masyarakat juga menjadi daya tarik untuk mengembangkan tanaman gandum. Faktor tunggal yang paling menentukan semangat masyarakat terhadap program yang kita tawarkan adalah peningkatan pendapatan perorangan yang dapat dicapai dengan ide program yang kita tawarkan (Bunch, 2001).

\section{SIMPULAN}

Respons masyarakat terhadap pengenalan tanaman gandum dan produk-produknya di Desa Arjasari, Kecamatan Arjasari, Kabupaten Bandung sangat baik. Hal ini terlihat setelah penyuluhan bahwa masyarakat tertarik menanam gandum dan membuat produk-produk dari gandum. Variabel yang berhubungan dengan ketertarikan masyarakat mengembangkan gandum adalah umur masyarakat, pengenalan produk sebelumnya, pernah tanam sebelumnya, dan minat menambah penghasilan.

\section{UCAPAN TERIMAKASIH}

Penulis mengucapkan terimakasih kepada Universitas Padjadjaran yang telah membiayai kegiatan pengabdian kepada masyarakat ini melalui skema PPMP Multi Tahun. 


\section{DAFTAR PUSTAKA}

Aptindo. 2014. Overview Industri Tepung Terigu Nasional Indonesia. Seminar Aptindo, 11 Juli 2014. Jakarta

Bunch, R. 2001. Dua Tongkol Jagung: Pedoman Pengembangan Pertanian Berpangkal pada Rakyat. Yayasan Obor Indonesia. Jakarta.

Budiarto, Eko. 2001. Biostatistika untuk Kedokteran dan Kesehatan Masyarakat. Penerbit Buku Kedokteran EGC. Jakarta.

Hasanuddin, T. 2005. Adopsi inovasi dalam kegiatan usahatani pada beberapa spesifik sosiobudaya petani di Propinsi Lampung. Jurnal Agrijati. Vol 1 (1).

Musyafak, A. dan T.M. Ibrahim. 2005. Strategi percepatan adopsi dan difusi inovasi pertanian mendukung prima tani. J. Anal. Kebij. Pert. Vol. $3(1): 20-37$
Nurmala, T. 1998. Serealia Sumber Karbohidrat Utama. Penerbit Rineka Cipta. Jakarta.

Nurmala, T. dan A.W. Irwan. 2007. Pangan Alternatif. Penerbit Giratuna. Bandung.

Nurmala, T., A.W. Irwan, A. Wahyudin, dan F.Y. Wicaksono. 2015. Agronomi Tropis. Penerbit Giratuna. Bandung.

Wicaksono, F.Y., T. Nurmala, A. W. Irwan, dan M. Kadapi. 2017. Ulasan pertumbuhan dan hasil tanaman gandum (Triticum aestivum L.) di dataran medium dengan beberapa rekayasa teknologi budidaya. Prosiding Semnas Pemberdayaan Masyarakat, 10 Desember 2016. Faperta UPN "Veteran". Yogyakarta.

World Wheat Production. 2016. World Wheat Production 2016/2017. Diakses tanggal 15 November 2016 dari https://www.worldwheatproduction.com/ 